\title{
ELABORATION OF HOLISTIC TOURIST SATISFACTION INDEX MODEL FOR LITHUANIA
}

\author{
Lina Pilelienè ${ }^{1}$, Viktorija Grigaliūnaitè $^{2}$
}

\begin{abstract}
As the importance of tourism managements is becoming recognized worldwide, many scholars start talking about tourist satisfaction as the main driver of the tourism sector. Satisfaction measurement and determination of its antecedents has become a field for tourism research and scientific discussion. Tourist satisfaction indices were started to elaborate for many countries (e.g., Malaysia, Mexico, Hong Kong, Croatia, etc.); however, considering satisfaction as a multifaceted construct, every single case has to be viewed and assessed separately. Achieving to complement to the body of knowledge, this manuscript proposes a holistic tourist satisfaction index model for Lithuania. The paper aims to aggregate the previously approved tourist satisfaction indices in a framework of Lithuania into a holistic model to be applied regarding the existing circumstances. The proposed model is a final step of the numerous previous researches, aggregating their results and proposing guidelines for tourist satisfaction improvement and loyalty assurance in a bundle of possible tourism-related situations regarding Lithuania as a place. The proposed holistic tourist satisfaction index model encompasses six previously elaborated models: Inbound tourist satisfaction index model; Emigrants' satisfaction index model; Outbound tourist satisfaction index model; The model of Lithuanian tourist satisfaction with European summer holiday destinations index; Local tourist satisfaction index model; and Rural tourist satisfaction index model; therefore, guidelines for any tourismrelated situation, whether it was domestic (local), inbound, or outbound tourism, are provided. Moreover, as in every situation, different antecedents of tourist satisfaction were determined; the holistic model stops practitioners, as well as scholars from taking unavailing decisions.
\end{abstract}

Key words: Lithuania, satisfaction model, tourism loyalty, tourism satisfaction.

JEL Classification: L83, Z32, Z33

\section{Introduction}

Tourism plays a significant role in every state's or region's economy (Cobb, 2003): it can be viewed as the industry of high importance because of its ability to create a space for employment and attract foreign money (Choovanichchannon, 2015). Castellano et al. (2019) emphasize that tourism development in a destination is often induced by tourist satisfaction. Furthermore, tourist satisfaction is often measured in order to assess the overall performance of tourism management in a destination (Song et al., 2011). Substantiating the benefits of tourist satisfaction, Saayman et al. (2018) emphasize that satisfied tourists bring a bundle of benefits to a destination, and tourist satisfaction is a determinant of consumption of products and services presently and in the future (Castellano et al., 2019).

Despite the number of methods for tourist satisfaction assessment found in the scientific literature, Song et al. (2011) emphasize that there are still a number of issues in the field to be resolved. Emphasizing the multidimensional nature of tourist satisfaction, Castellano et al. (2019) argue that every single attribute of tourist satisfaction plays a role in an overall picture; therefore, a composite understanding of the phenomenon is needed.

In order to thoroughly assess tourist satisfaction, a worldwide trend of elaborating tourist satisfaction indices can be observed. Substantiating the creation of such indices, Song et al. (2012) state: 'the development of a consumerbased system for evaluating tourism service performance that focuses on tourist satisfaction is of great importance for tourist destination management.' Therefore, this manuscript will contribute to the body of knowledge in the field by proposing a holistic tourist satisfaction index model for Lithuania. Accordingly, the goal of current research is to aggregate the previously approved tourist satisfaction indices in a framework of Lithuania into a holistic model to be applied regarding the existing circumstances.

\footnotetext{
Corresponding author:

${ }^{1}$ Vytautas Magnus University, Lithuania.

E-mail: lina.pileliene@vdu.lt

${ }^{2}$ Vytautas Magnus University, Lithuania.

E-mail: viktorija.grigaliunaite@vdu.lt
} 
Achieving to elaborate the holistic tourist satisfaction index model for Lithuania, previously elaborated index models (i.e. inbound tourist satisfaction index model; emigrants' satisfaction index model; outbound tourist satisfaction index model; the model of Lithuanian tourist satisfaction with European summer holiday destinations index; local tourist satisfaction index model; rural tourist satisfaction index model) are aggregated and combined to form a complete background for tourist satisfaction assessment in all the possible situations regarding Lithuanian tourism.

To form the research logic, the manuscript is divided into introduction, four parts (sections 2 nd to 5 th), and conclusions. In order to highlight the topicality of the paper, in section 2, the multidimensional conception of tourist satisfaction is disclosed; in section 3 , the determinants of tourist satisfaction forming the index models are provided; in section 4, loyalty as the main consequence of tourist satisfaction is analysed; and finally, the holistic model is constructed in section 5 .

\section{The conception of tourist satisfaction}

During the past several decades, customer satisfaction has become a topic of interest for many scholars and marketers (Song et al., 2011). Tourist satisfaction, therefore, can be viewed as a form of customer satisfaction in a field of tourism. According to Castellano et al. (2019), 'tourist satisfaction is a multifaceted phenomenon, the understanding of which requires fully integrated and multidimensional interpretative frameworks.' Substantiating the necessity for tourist satisfaction assessment, Song et al. (2011) emphasize its impact on the reputation of tourist destination, as well as on companies operating in it. Oviedo-García et al. (2019) emphasize that in line with tourist satisfaction goes tourist perceived value; and both have to be viewed as principle elements of tourist experience shaping.

Analysing tourist satisfaction, Oviedo-García et al. (2019) point out that satisfaction is shaped by tourist experience, which is combined of different inputs. According to Song et al. (2011), tourism has to be viewed as a system composed of a number of components (e.g. accommodation and catering) forming experience as a whole; therefore, satisfaction with every single component will result in the overall satisfaction with the destination. Accordingly, tourist satisfaction measurement is often based on an assessment of multiple destination-related attributes (Saayman et al., 2018); such attributes as quality of services, price level at a destination, cleanliness and infrastructure of the environment often contribute to tourist's perception and experience of the destination and make an impact on overall satisfaction with it.

\section{Determinants of tourist satisfaction}

Being multifaceted in its nature, tourism satisfaction is often assessed as a consequence of a bundle of its determinants. Despite a longevous practice in the field of tourist satisfaction assessment, the consensus regarding its determinants still hasn't been reached.

Assessing tourist satisfaction in China, Song et al. (2011) provide four its antecedents: tourist characteristics; perceived performance; assessed value, and expectations. Latter factors affect overall satisfaction with a tourism-related experience. However, a year later, the same authors (Song et al., 2012) provided Hong Kong tourist satisfaction index already composing six determinants: attractions, hotels, immigration, restaurants, retail shops, and transportation. Martin, Saayman and du Plessis (2019) name only four determinants of international tourist satisfaction: accommodation, attraction, food and beverages, and immigration, comprising aggregate service satisfaction having an impact on the overall destination satisfaction. Creating the index of destination attractiveness for Croatia, Krešic and Prebežac (2011) provided six determinants of tourist satisfaction: accommodation and catering facilities; activities in the destination; natural features; destination aesthetics; environmental preservation; and destination marketing. Kalantari, Sembada, and Gholipour (2019) used six dimensions (i.e. nature, physical activities, novelty/learning, mundane, social, and ego/status) in the questionnaire to measure the relationship between tourist motivation and participation. Also, other tourist satisfaction with different touristic places indices composed by various determinants can be named and analysed (e.g., international tourists satisfaction with Jordan by Al-Majali (2012); Indian tourists' satisfaction of Bangkok, Thailand by Siri et al. (2012); etc.); however, the diversity of elements used implies that despite the differences in their naming, the determinants are also very similar.

After a thorough evaluation of various indices of tourism satisfaction in a framework of different countries, the typology of tourism-related aspects to be included into the index as the determinants of satisfaction provided by Krešic and Prebežac (2011) was considered to be the most reflecting and suitable to be applied in all the tourism-related situations.

\section{Loyalty as a consequence of tourist satisfaction}

Song et al. (2011) emphasize that well-managed tourist satisfaction results in the increase of customer loyalty, which in turn can be observed in lower price sensitivity, a reduced future transaction costs, and also better awareness of a destination. Substantiating their tourist loyalty index, Cossío-Silva, Revilla-Camacho, and Vega-Vázquez (2019) emphasize that 'the usefulness 
of measuring loyalty lies in being able to apply strategies which enable improving it.' Substantiating the necessity of loyalty management, Song et al. (2011) detected a positive link between tourist satisfaction and loyalty: a higher level of satisfaction resulted in increased loyalty.

Akhoondnejad (2018) emphasizes that in a context of consumption loyalty primarily was viewed as a behavioural manifestation repurchase, consumption, consumer relationship, or a mixture of them regarding the same vendor; whereas attitudinal loyalty resulted in consumer intentions to recommend or repurchase. Therefore, in the case of tourism, behavioural loyalty results in intention to revisit a place; and attitudinal in intention to recommend it.

Consequently, while elaborating the index of tourist satisfaction, loyalty has to be included as its main antecedent.

\section{Holistic tourist satisfaction index model for Lithuania}

Determining the satisfaction of international tourists, Martin, Saayman, and du Plessis (2019) emphasize that tourist satisfaction is often being assessed within the framework of five constraints:

1) a destination being an object of tourist satisfaction;

2) the population which evaluates their satisfaction with the destination;

3) the scale being used for the assessment;
4) theoretical approach directing the measured items; 5) the model used for the research.

In this manuscript, the destination chosen for the index creation is Lithuania - a country of the European Union being located in Central Europe.

While deciding on the population for the research, the tourists depending on their traveling purposes in relation to Lithuania were chosen. To be more precise: tourists were chosen regarding tourism classification. As it can be found in the scientific literature (e.g. Dwyer et al, 2016; Huang, Weiler, 2010; etc.), tourism can be classified into inbound, outbound, and domestic or local. Furthermore, inbound tourism can be further classified into inbound and emigrants' tourism; local tourism can be further classified into local and rural tourism and outbound tourism can be further classified based on the specific criteria, e.g. purpose of tourism - leisure or business, where further tourism classifications can be made for each of the mentioned purpose based on many criteria. For example, leisure tourism can be further classified based on holiday destinations (e.g. summer holiday destinations, winter holiday destinations, etc.) and business tourism can be further classified based on the industry classification (e.g., medical tourism (Borg, Ljungbo, 2018); food tourism (Robinson, Getz, Dolnicar, 2018); shopping tourism (Choi, Law, Heo, 2018); etc.) (Figure 1).

Regarding the three final constraints of tourist satisfaction assessment (the scale; the measured

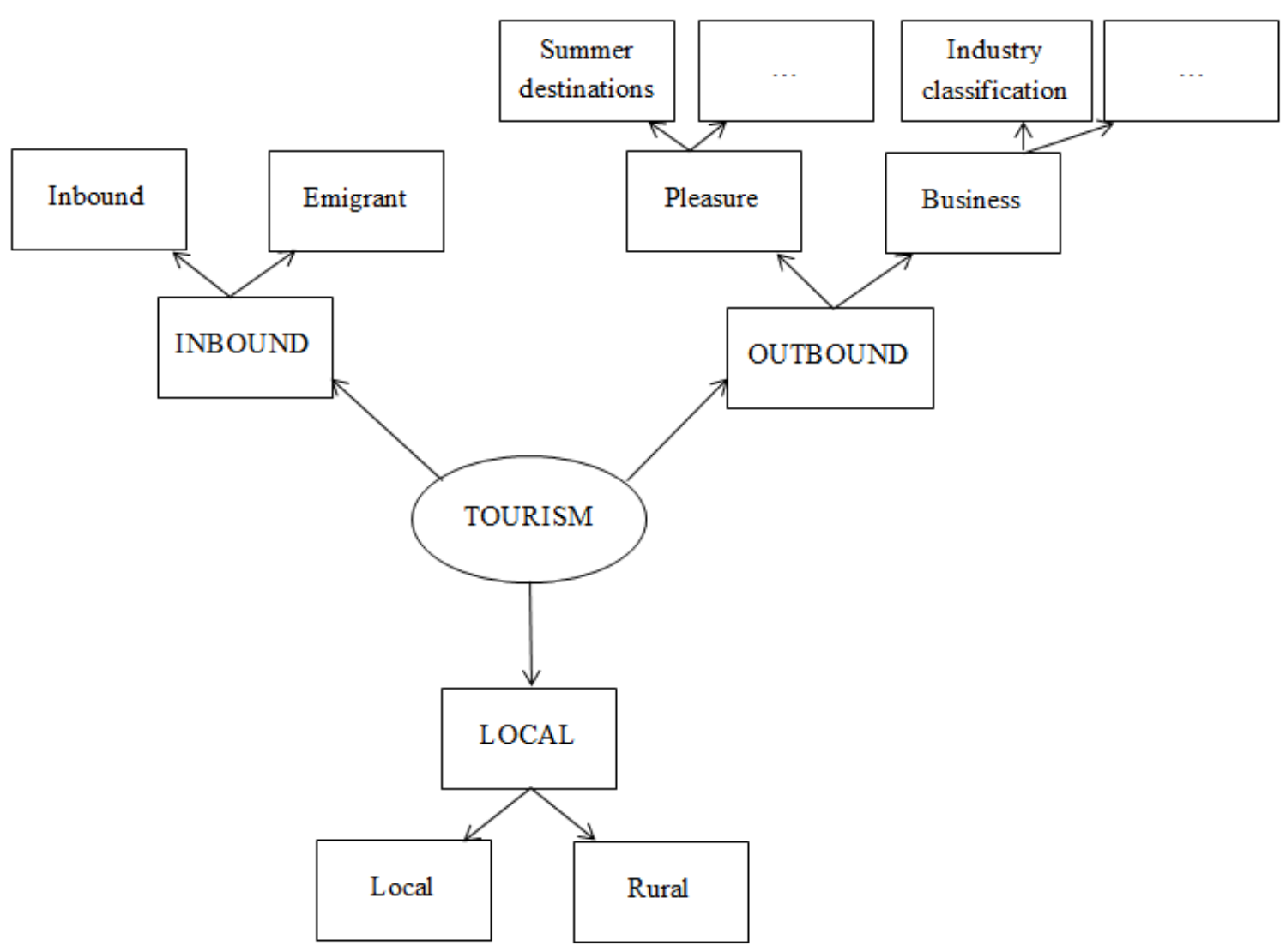

Figure 1. Tourism classification 
items; and the model), the holistic Lithuanian tourist satisfaction index model is being created based on data from six previously elaborated models regarding different research populations and their relation to Lithuania:

1) Inbound tourist satisfaction index model (Pileliené, Grigaliūnaitè, 2016);

2) Emigrants' satisfaction index model (Grigaliūnaitè, Pilelienè, 2019a);

3) Outbound tourist satisfaction index model (Pileliené, Grigaliūnaitè, 2014a);

4) The model of Lithuanian tourist satisfaction with European summer holiday destinations index (Pilelienè, Grigaliūnaitè, 2018);
5) Local tourism satisfaction index model (Grigaliūnaitè, Pileliené, 2019b);

6) Rural tourism satisfaction index model (Pilelienè, Grigaliūnaitè, 2014b).

Inbound tourist satisfaction index model, revealing factors affecting tourist satisfaction with Lithuania, is presented in Figure 2 below. As can be seen, tourist satisfaction with Lithuania is influenced by accommodation and catering, destination aesthetics, destination marketing, and activities in the destination and influences tourist loyalty.

The model of Lithuanian emigrants' satisfaction with their holiday in Lithuania index is presented in Figure 3.

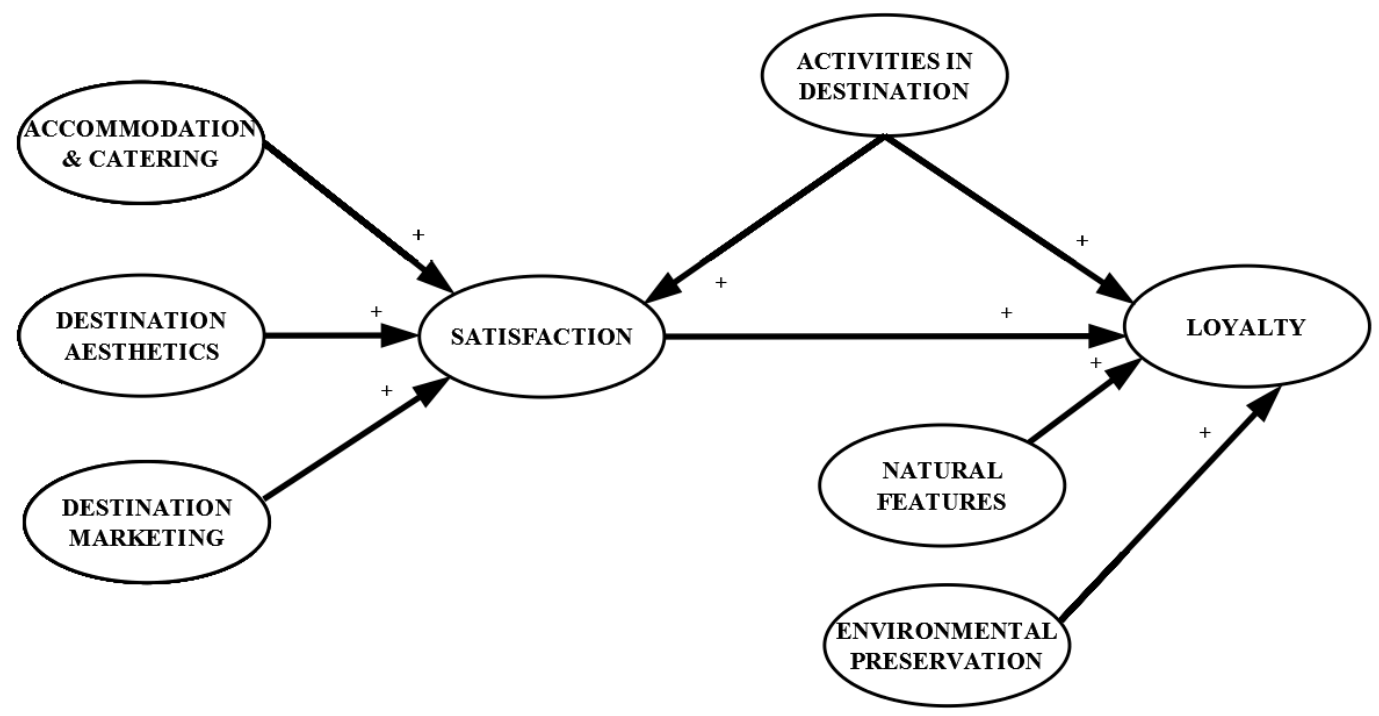

Figure 2. Inbound tourist satisfaction index model

Source: Pilelienè, Grigaliūnaitè (2016)

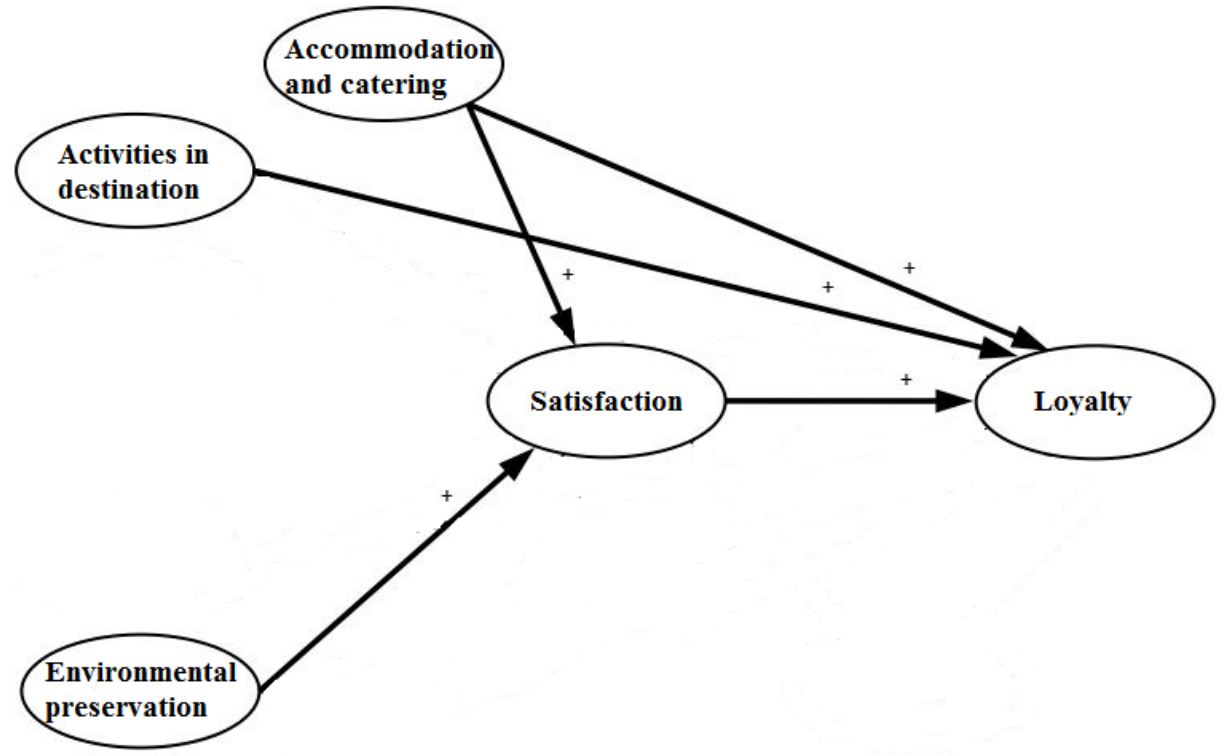

Figure 3. Emigrants' satisfaction index model

Source: Grigaliūnaitè, Pilelienè (2019a) 
As can be seen, accommodation and catering influence inbound tourist satisfaction with Lithuania in general case and in the case of emigrants' satisfaction. Nevertheless, in latter case emigrants' satisfaction is influenced by environmental preservation, which is not relevant in the general case of inbound tourist satisfaction with Lithuania. Moreover, emigrants' satisfaction is not influenced by destination aesthetics, destination marketing, and activities in destination, which are relevant factors in the general case of inbound tourist satisfaction with Lithuania.

Outbound tourist satisfaction index model revealing factors affecting Lithuanian tourist satisfaction in the general case of outbound tourism is presented below in Figure 4. As can be seen, outbound tourist satisfaction is influenced by activities in destination, destination marketing, environmental preservation, and natural features. When compared to the inbound tourist satisfaction index model, it can be seen that two variables differ: in the case of inbound tourism, accommodation and catering and destination aesthetics influence satisfaction, while in the case of outbound tourism, instead of latter factors, natural features and environmental preservation influence satisfaction.

In the specific case of Lithuanian tourist satisfaction with European summer holiday destinations as a part of outbound tourism, factors affecting Lithuanian tourist satisfaction differ from the general case. As can be seen from Figure 5, in the case of Lithuanian tourist satisfaction with European summer holiday destinations, environmental preservation is not a relevant factor for tourist satisfaction. Instead, accommodation and catering is the factor influencing tourist satisfaction.

Local tourist satisfaction index model is presented in Figure 6 below. As can be seen, tourist satisfaction is influenced by accommodation and catering, destination aesthetics, destination marketing, and environmental preservation. Consequently, it could be stated that latter

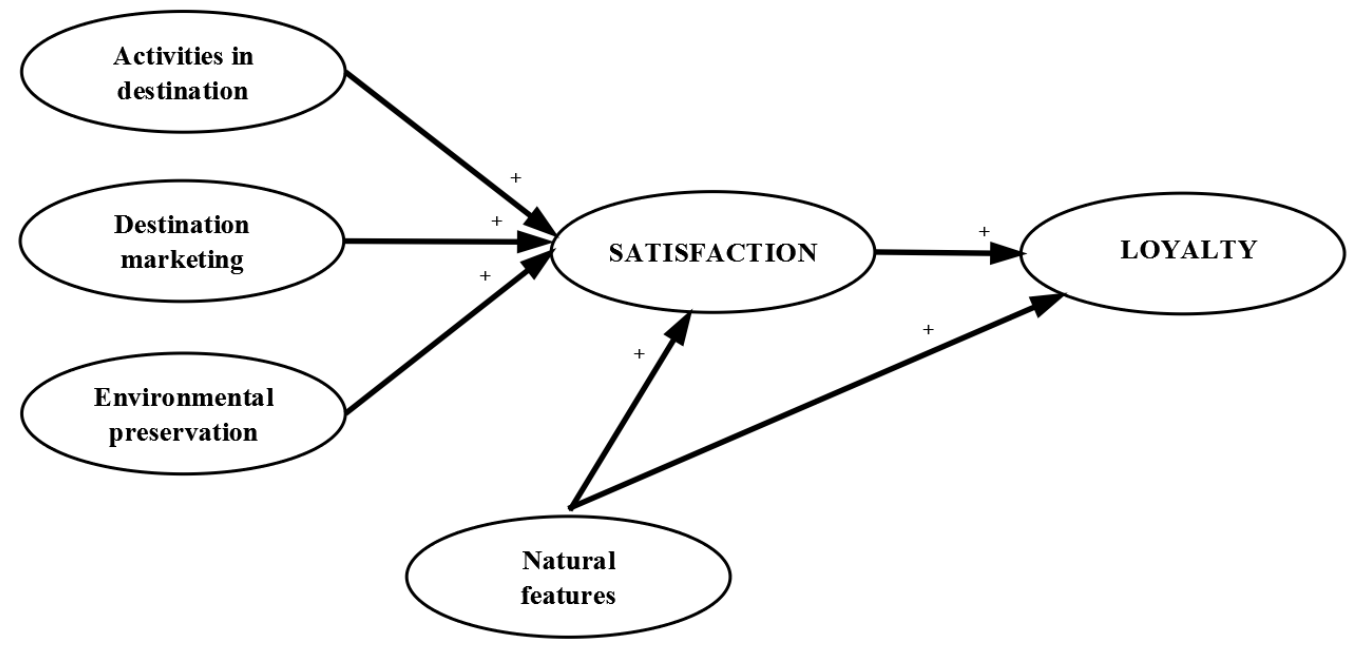

Figure 4. Outbound tourist satisfaction index model Source: Pilelienè, Grigaliūnaitè (2014a)

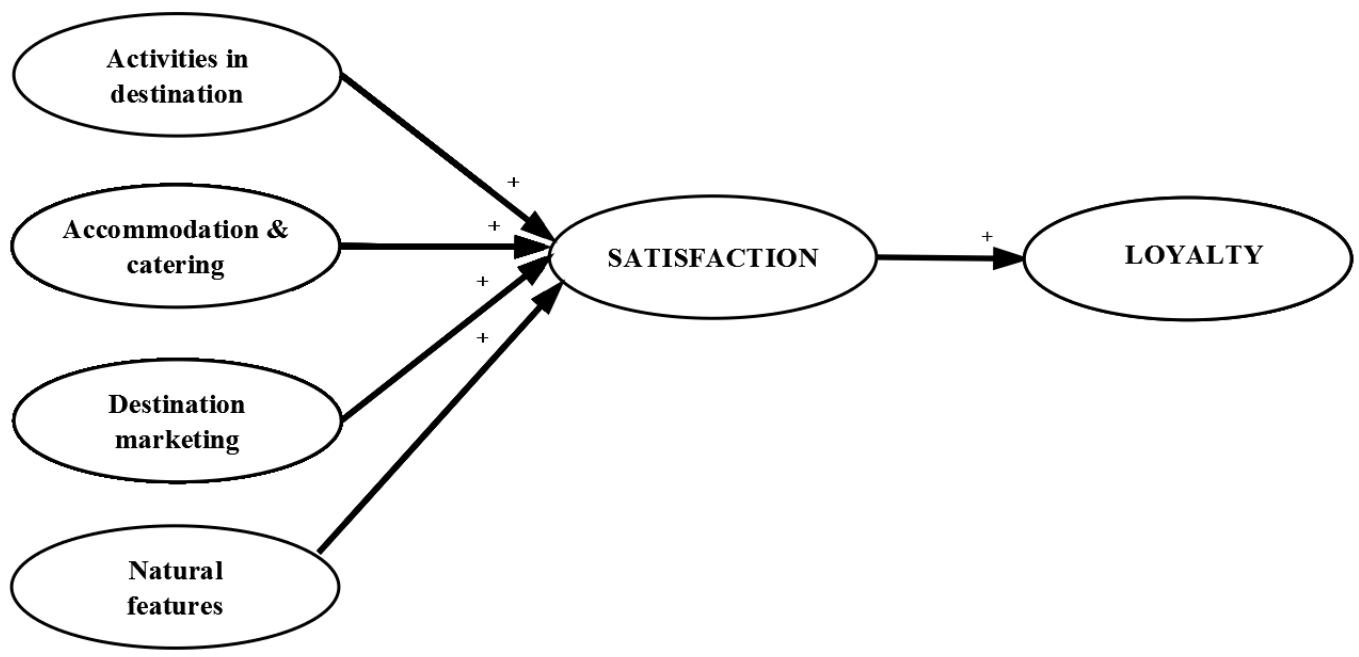

Figure 5. The model of Lithuanian tourist satisfaction with European summer holiday destinations index Source: Pilelienè, Grigaliūnaitè (2018) 


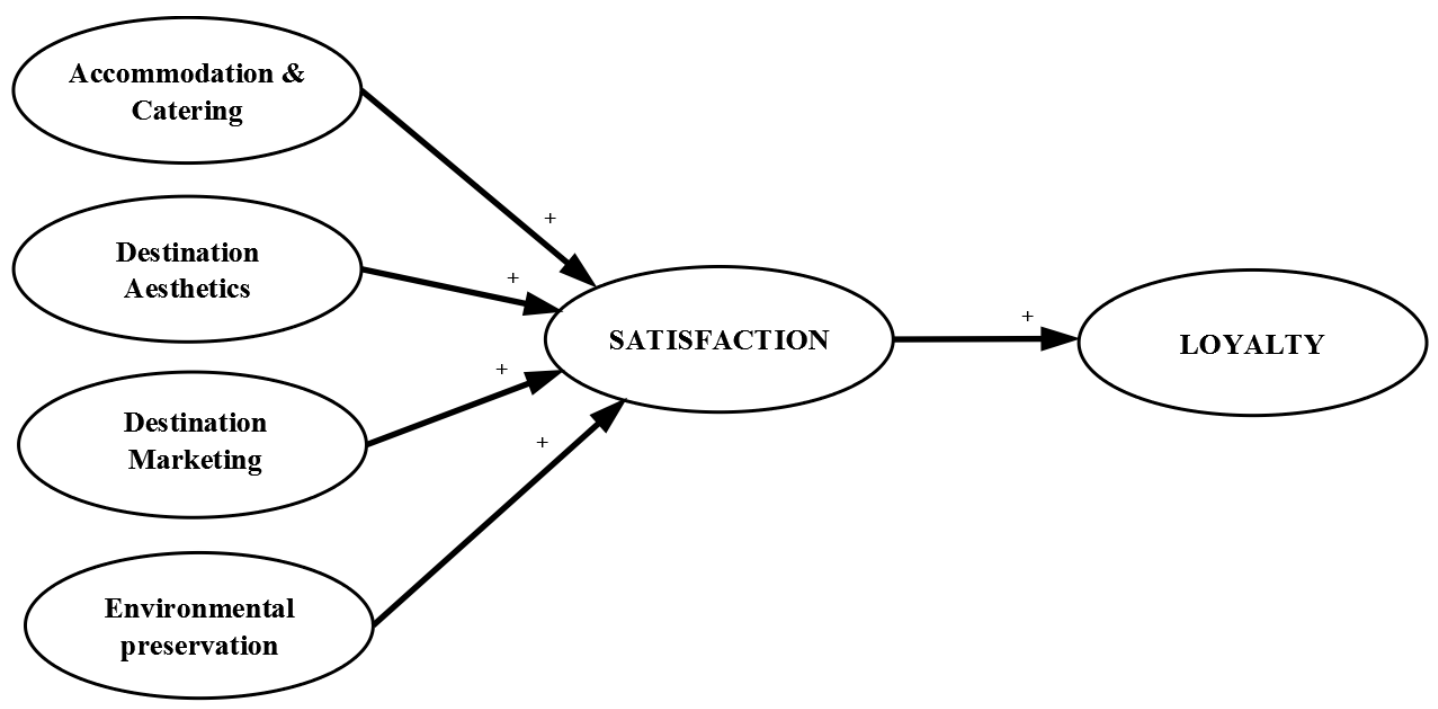

Figure 6. Local tourist satisfaction index model

Source: Grigaliūnaitè, Pilelienè (2019b)

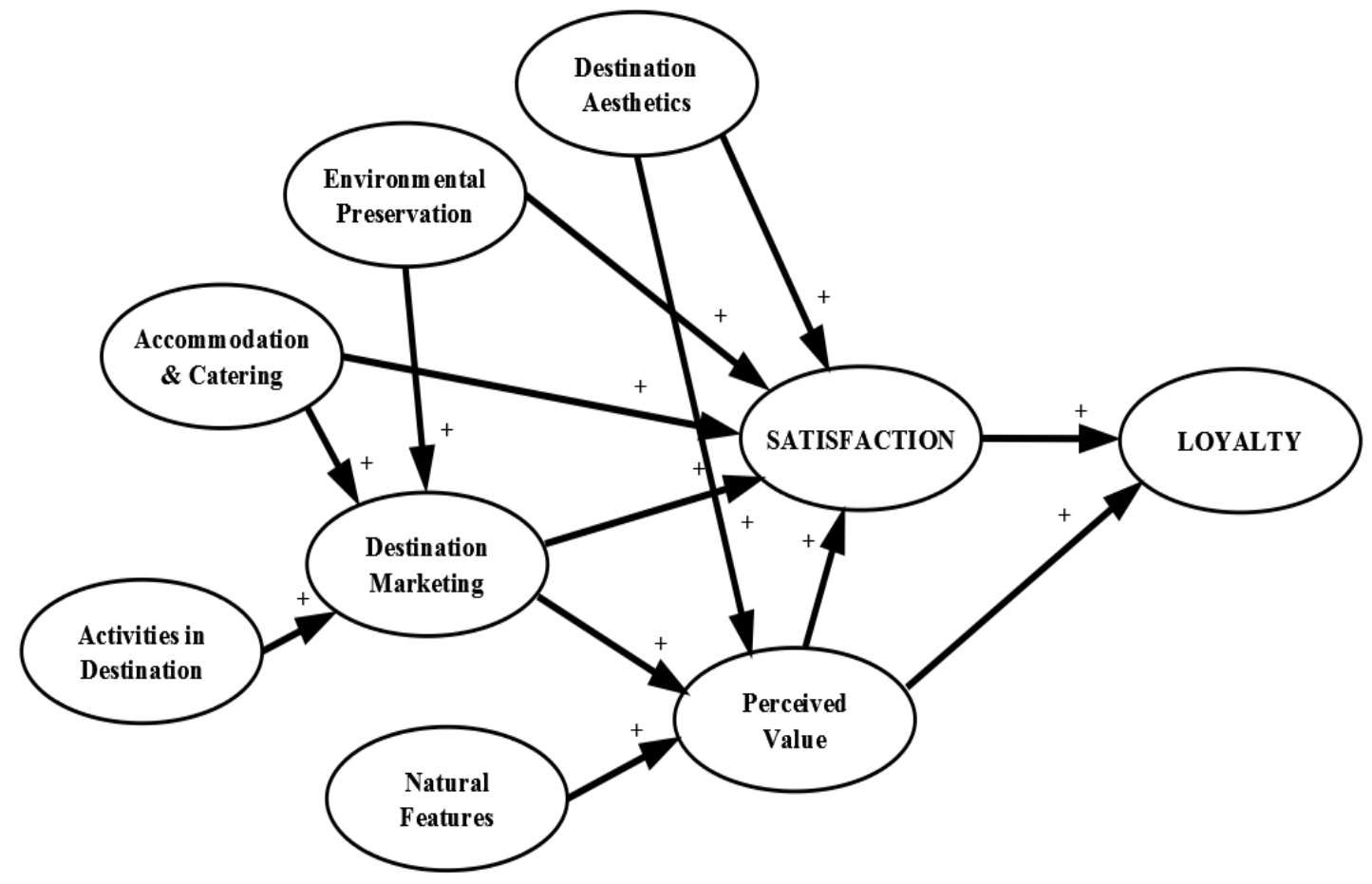

Figure 7. Rural tourism satisfaction index model

Source: Pilelienè, Grigaliūnaitè (2014b)

model is very similar to the inbound tourist satisfaction index model, except for the one factor - environmental preservation, which is relevant in the case of outbound tourist satisfaction index model.

In the specific case of local tourism - rural tourism, factors affecting tourist satisfaction are presented in the elaborated rural tourist satisfaction index model provided below in Figure 7. As can be seen, tourist satisfaction in the case of rural tourism is influenced by the same four factors that influence local tourist satisfaction in the general case - accommodation and catering, destination aesthetics, destination marketing, and environmental preservation. Despite this, in the case of rural tourism, tourist satisfaction is influenced by the additional factor - perceived value.

Based on all elaborated models, the holistic Lithuanian tourist satisfaction index model is composed and provided in Figure 8. Based on the elaborated model, when seeking to enhance the level of inbound tourism in Lithuania, destination aesthetics, destination marketing, activities in destination, and accommodation and catering in the destination should be properly managed. 


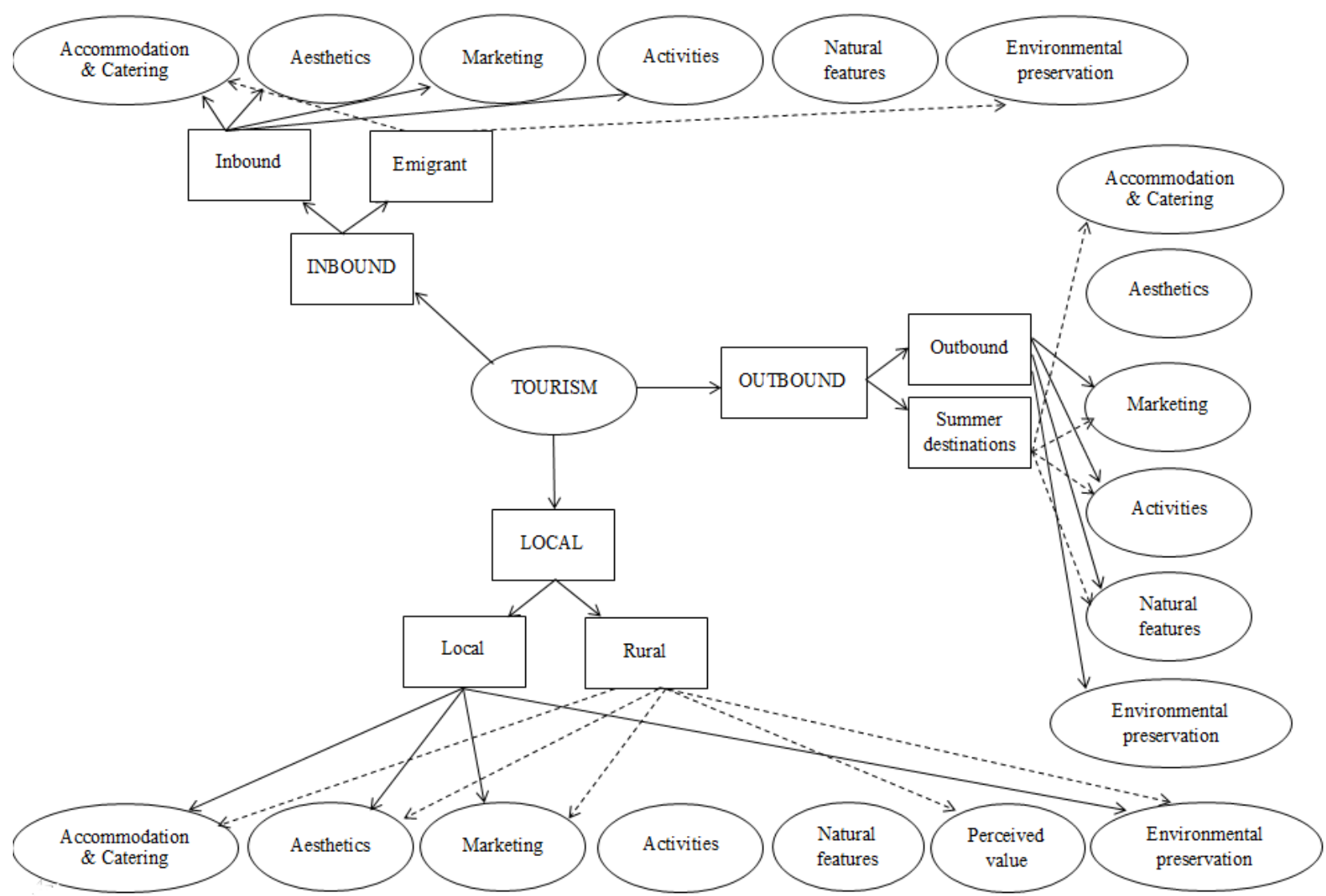

Figure 8. Holistic Lithuanian tourist satisfaction index model

In the specific case of inbound tourism, when seeking to attract more emigrants to the homeland for holiday, environmental preservation and accommodation and catering as well should be properly managed.

When seeking to enhance the level of outbound tourism in Lithuania, destination marketing, activities in destination, natural features, and environmental preservation are the factors that must be taken into consideration. In the specific case of outbound tourism, when seeking to attract more Lithuanian tourists to the European summer holiday destinations, destination marketing, activities in destination, natural features, and accommodation and catering should be properly managed.

Finally, when seeking to enhance the level of local tourism in Lithuania, accommodation and catering, destination marketing, destination aesthetics, and environmental preservation are the factors that must be taken into consideration. Moreover, in the specific case of local tourism, when seeking to enhance the level of rural tourism, not only the abovementioned factors should be managed properly but the new factor - perceived value should be taken into consideration as well.

\section{Conclusions}

The paper aimed to aggregate the previously approved tourist satisfaction indices in a framework of Lithuania into a holistic model to be applied regarding the existing circumstances. Therefore, the holistic tourist satisfaction index model for Lithuania was composed.

Based on the analysis of scientific literature in a field of tourist satisfaction, it can be stated that the scholars agree on the importance of tourist satisfaction measurement and on its tremendous impact on the economy. Moreover, all the analysed indices of tourist satisfaction used tourist loyalty as the main antecedent manifesting in behavioural or attitudinal (of a mixture of both) way. However, despite the consensus regarding the importance of tourist satisfaction and loyalty, the determinants of tourist satisfaction remain under discussion.

After analysing various tourist satisfaction indices (China, Hong Kong, Croatia, Thailand, etc.), it can be concluded that the analysed determinants varied by country. However, being different they can also be grouped into several categories reflecting overall tourist experience. Based on the essence of determinants included into tourist satisfaction indices, six categories can be named as encompassing most: accommodation and catering facilities; activities in the destination; natural features; destination aesthetics; environmental preservation; and destination marketing.

The proposed determinants, as well as customer loyalty as a consequence of the tourist satisfaction, were combined into tourist satisfaction index, which 
was verified in different situations regarding Lithuanian tourism. The obtained resultsindicate that the antecedentrelated part of the index is not only country-specific but also situation-specific. Therefore, it is recommended for tourism practitioners, as well as scholars working in the field, to consider provided guidelines in order to enhance tourist satisfaction and achieve loyalty.

Considering research limitations, they can be viewed in line with further research directions. The general tourist satisfaction index can be tested regarding different holidayor pleasure-related situations, e.g.: winter holiday, Pacific holiday, etc. Moreover, the model can obtain a different composition in a framework of different industries, e.g.: culinary tourism, shopping tourism, etc. Based on the research results, it can be assumed that the model might work differently in a situation regarding different country. Therefore, a field for further scientific as well as empiric research can be envisioned.

\section{References:}

Akhoondnejad, A. (2018). Loyalty formation process of tourists in sporting event: The case of Turkmen horse races. Journal of Hospitality and Tourism Management, Vol. 34, p. 48-57. doi: 10.1016/j.jhtm.2017.11.006

Borg, E. A., \& Ljungbo, K. (2018). International Market-Oriented Strategies for Medical Tourism Destinations. International Journal of Market Research, Vol. 60, issue 6, p. 621-634. doi: 10.1177/1470785318770134

Castellano, R., Chelli, F. M., Ciommi, M., Musella, G., Punzo, G., \& Salvati, L. (2019). Trahit sua quemque voluptas. The Multidimensional Satisfaction of Foreign Tourists Visiting Italy. Socio-Economic Planning Sciences, In press, corrected proof. doi: 10.1016/j.seps.2019.06.007

Choi, M., Law, R., \& Heo, C. Y. (2018). An Investigation of the Perceived Value of Shopping Tourism. Journal of Travel Research, Vol. 57, issue 7, pp. 962-980. doi:10.1177/0047287517726170

Choovanichchannon, Ch. (2015). Satisfaction in Thai Standard of Tourism Quality. Procedia-Social and Behavioral Sciences, Vol. 197, pp. 2110-2114.

Cobb, K. (2003). State makes top dozen. Fedgazette, Vol. 15, issue 3, p. 16.

Cossío-Silva, F.-J., Revilla-Camacho, M.Á., \& Vega-Vázquez, M. (2019). The tourist loyalty index: A new indicator for measuring tourist destination loyalty? Journal of Innovation \& Knowledge, Vol. 4, issue 2, p. 71-77. doi: 10.1016/j.jik.2017.10.003 Dwyer, L., Pham, T., Jago, L., Bailey, G., \& Marshall, J. (2016). Modeling the Impact of Australia's Mining Boom on Tourism. Journal of Travel Research, Vol. 55, issue 2, pp. 233-245. doi: 10.1177/0047287514541007

Grigaliūnaitè, V., \& Pilelienè, L. (2019a). Factors Affecting Emigrants' Satisfaction with their Holiday in Homeland Lithuania. DEMSME 2019: 2nd international conference on Decision making for small and medium-sized enterprises, Ostrava, Czech Republic, May 16-17, 2019: conference proceedings, pp. 96-102.

Grigaliūnaite, V., \& Pilelienè, L. (2019b). Local Tourist Satisfaction with their Holiday in Lithuania. Economic science for rural development 2019: proceedings of the 20th international scientific conference, Jelgava. No. 51: Integrated and sustainable regional development marketing and sustainable consumption, pp. 284-290.

Huang, S., \& Weiler, B. (2010). A Review and Evaluation of China's Quality Assurance System for Tour Guiding. Journal of Sustainable Tourism, Vol. 18, issue 7, pp. 845-860. doi: 10.1080/09669582.2010.484492

Kalantari, H. D., Sembada, A. Y., \& Gholipour, H. F. (2019). Tourist Satisfaction in 'All-in-One' Branded Destinations. Annals of Tourism Research, In press, corrected proof. doi: 10.1016/j.annals.2019.04.001

Krešic, D., \& Prebežac, D. (2011). Index of destination attractiveness as a tool for destination attractiveness assessment. TOURISM - An International Interdisciplinary Journal, Vol. 59, issue 4, pp. 497-517.

Martin, J. C., Saayman, M., \& du Plessis, E. (2019). Determining Satisfaction of International Tourist: A Different Approach. Journal of Hospitality and Tourism Management, Vol. 40, pp. 1-10. doi: 10.1016/j.jhtm.2019.04.005

Oviedo-García, M. Á., Vega-Vázquez, M., Castellanos-Verdugo, M., \& Orgaz-Agüera, F. (2019). Tourism in Protected Areas and the Impact of Servicescape on Tourist Satisfaction, Key in Sustainability. Journal of Destination Marketing and Management, Vol. 12, p. 74-83. doi: 10.1016/j.jdmm.2019.02.005

Pilelienè, L., \& Grigaliūnaitè, V. (2016). The Index of Tourist Satisfaction with Lithuania. European Journal of Tourism, Hospitality and Recreation, Vol. 7, issue 1, pp. 30-39.

Pilelienè, L., \& Grigaliūnaitè, V. (2014a). Lithuanian Tourist Satisfaction Index Model. European Journal of Tourism, Hospitality and Recreation, Vol. 5, issue 1, pp. 35-51.

Pilelienè, L., \& Grigaliūnaite, V. (2014b). Rural Tourist Satisfaction Index: A Case of Lithuania. Research for rural development: annual 20 th international scientific conference proceedings, Vol. 2, pp. 271-277.

Pilelienè, L., \& Grigaliūnaitè, V. (2018). Lithuanian Tourist Satisfaction with European Summer Holiday Destinations. 4th International Conference EATSA 2018: Challenges of tourism development in Asia \& Europe, France, Dijon, June 18-22. Robinson, R. N. S., Getz, D., \& Dolnicar, S. (2018). Food Tourism Subsegments: A Data-Driven Analysis. International Journal of Tourism Research, Vol. 20, issue 3, pp. 367-377. doi: 10.1002/jtr.2188

Saayman, M., Li, G., Uysal, M., \& Song, H. (2018). Tourist Satisfaction and Subjective Well-Being: An Index Approach. International Journal of Tourism Research, Vol. 20, issue 3, p. 388-399. doi: 10.1002/jtr.2190

Song, H., Li, G., van der Veen, R., \& Chen, J. L. (2011). Assessing Mainland Chinese Tourists' Satisfaction with Hong Kong Using Tourist Satisfaction Index. International Journal of Tourism Research, Vol. 13, issue 1, pp. 82-96. doi: 10.1002/jtr.801

Song, H., van der Veen, R., Li, G., \& Chen, J. L. (2012). The Hong Kong Tourist Satisfaction Index. Annals of Tourism Research, Vol. 39, issue 1, pp. 459-479. doi: 10.1016/j.annals.2011.06.001 